\title{
PRAKTIK PEMBERIAN ASI DAN WAKTU PELEPASAN TALI PUSAT BAYI BARU LAHIR
}

\section{Breastfeeding Practice and Time of Umbilical Cord Detachment in Newborn}

\author{
Ifana Syafira Maharani ${ }^{1}$, Ika Yudianti ${ }^{2}$ \\ ${ }^{1,2}$ Program Studi Sarjana Terapan Kebidanan, Jurusan Kebidanan. Poltekkes Kemenkes Malang \\ ikyudmidwife@gmail.com
}

\begin{abstract}
ABSTRAK
Tali pusat yang masih menempel pada perut bayi dapat menjadi tempat masuknya mikroorganisme, sehingga semakin cepat tali pusat mengering dan lepas akan mengurangi risiko terjadinya infeksi tali pusat. Penelitian ini bertujuan untuk mengetahui perbedaan waktu pelepasan tali pusat bayi yang mendapatkan ASI dibandingkan dengan kombinasi ASI dan susu formula. Desain penelitian adalah analitik komparatif dengan pendekatan cross sectional. Sampel adalah bayi baru lahir di PMB Ngadillah Kec. Pakis Kab. Malang sejumlah 32 bayi, dikelompokkan menjadi dua yakni 16 bayi ASI eksklusif dan 16 bayi mendapatkan kombinasi ASI dan susu formula. Sampel diambil menggunakan teknik accidental. Instrumen penelitian menggunakan kuesioner terpimpin dan lembar observasi. Uji hipotesis menggunakan Independent T-Test dan didapatkan $p$ value $=0,006$ yang artinya ada perbedaan waktu pelepasan tali pusat bayi yang mendapatkan ASI dibandingkan dengan kombinasi ASI dan susu formula. Rerata waktu pelepasan tali pusat bayi pada kelompok ASI adalah 5 hari dan pada kelompok kombinasi ASI dan susu formula adalah 6 hari. Rekomendasi penelitian adalah memberikan ASI eksklusif untuk mempercepat pelepasan tali pusat bayi.
\end{abstract}

Kata Kunci: ASI, pelepasan tali pusat

\begin{abstract}
Umbilical cord is a port d entry for microorganisms, therefore the faster umbilical cord detache means the lower risk of umbilical cord infection. This study aims to determine the differences umbilical cord detachment time in newborns who get only breast milk compare to those with combination of breast milk and formula. Study design used was comparative analytic with cross sectional approach. Sample are newborns at Ngadillah-private midwife practice with a total of 32, divided to two groups consisting 16 newbonrs with breast milk only and 16 newborns with combination of breast milk and formula. Accidental sampling technique applied. Instrument used was questionnaire and observation sheet. Hypothesis tested with independent T-Test and obtained $p$ value of 0.006, which means there is a difference in umbilical cord detachment time in newborns with breast milk only compare to combination of breast milk and formula. The average time of the umbilical cord detachment in the breastfed group is 5 days and in the combination breastfed and formula milk group is within 6 days. So umbilical cord detachment time on breastfed group is faster than the combination of breast milk and formula milk group.
\end{abstract}

Keywords : breastmilk, formula milk, umbilical cord detachment

\section{PENDAHULUAN}

Segera setelah lahir, bayi secara fisiologis dapat hidup sendiri tanpa bantuan dari plasenta, oleh karena itu dilakukan tindakan pengikatan dan pemotongan pada tali pusat. Namun, kondisi bayi saat baru lahir hingga tahun pertama kehidupannya sangat rentan terkena resiko infeksi dikarenakan sistem kekebalan tubuhnya masih belum bekerja secara sempurna. Sehingga pada masa ini resiko kematian bayi baru lahir sangatlah tinggi.

Angka Kematian Bayi (AKB) merupakan indikator yang lazim digunakan untuk menentukan derajat kesehatan masyarakat. Menurut Hasil Survei Penduduk Antar Sensus (SUPAS) 2015 yang terdapat dalam profil kesehatan Indonesia tahun 2016, menunjukkan AKB di Indonesia sebesar 22,23 per 1.000 kelahiran hidup. Sedangkan menurut profil kesehatan provinsi Jawa Timur pada tahun 2016, AKB di Jawa Timur 
mencapai 23,6 per 1000 kelahiran hidup. Penyebab kematian neonatus $<28$ hari adalah sepsis (20,5\%), kelainan kongenital (19\%), pneumonia (17\%), Respiratory Distress Syndrome (RDS) (14\%), dan prematuritas (14\%). Sedangkan menurut profil kesehatan Kabupaten Malang tahun 2016 terdapat 4,52 kematian bayi per 1000 kelahiran hidup.

Salah satu jenis infeksi yang sering terjadi pada neonatus dan menyebabkan mortalitas yang tinggi adalah Tetanus Neonatorum. Menurut profil kesehatan provinsi Jawa Timur tahun 2016, jumlah kasus Tetanus Neonatorum di Provinsi Jawa Timur tahun 2016 adalah sebanyak 19 kasus, dan 4 diantaranya meninggal dunia. Penyakit ini disebabkan oleh spora Clostridium Tetani yang masuk melalui luka tali pusat. Hal ini dapat terjadi karena pemotongan tali pusat yang tidak higienis serta perawatan tali pusat yang tidak benar, karena luka tali pusat merupakan tempat masuknya mikroorganisme yang dapat menyebabkan infeksi neonatorum, dan dapat berkembang menjadi sepsis. Selain spora Clostridium Tetani, penyebab lain penyakit ini yaitu ibu hamil tidak mendapatkan imunisasi TT lengkap sehingga bayi yang dikandungnya tidak kebal terhadap penyakit Tetanus Neonatorum (Abata, 2015).

Teknik perawatan pada saat pemotongan dan mengikat tali pusat, serta perawatan tali pusat merupakan prinsip utama yang sangat penting untuk mencegah terjadinya sepsis karena infeksi tali pusat. Perawatan tali pusat yang tidak benar mengakibatkan tali pusat menjadi lama lepas. Resiko bila tali pusat lama lepas adalah terjadinya infeksi tali pusat dan penyakit tetanus neonatorum. Sehingga perawatan tali pusat perlu diperhatikan. Bila tali pusat basah, berbau dan menunjukkan tanda-tanda infeksi, harus waspada terhadap infeksi tali pusat. Perawatan tali pusat yang benar adalah berdasarkan prinsip-prinsip aseptik dan kering serta tidak lagi dianjurkan untuk menggunakan alkohol ataupun ramuanramuan lainnya, serta tidak ditutup rapat. Meskipun bisa ditutup, boleh menggunakan kain kassa steril dan tidak diikat terlalu kuat. Selain dengan metode bersih dan kering diatas, perawatan tali pusat juga dapat dilakukan dengan metode pemberian ASI.

Menurut hasil penelitian Eni Subiastutik (2012) tentang Efektifitas pemberian topikal ASI dibanding perawatan kering terhadap kecepatan waktu lepas tali pusat, perawatan tali pusat yang baik dan benar akan menimbulkan dampak yang positif yaitu tali pusat akan pupus pada hari ke-5 dan hari ke-7 tanpa ada komplikasi pada bayi. Tali pusat merupakan tempat masuknya mikroorganisme bagi bayi, oleh karena itu semakin cepat tali pusat lepas maka akan mengurangi terjadinya resiko infeksi tali pusat pada bayi.

Penelitian serupa dilakukan oleh Elsobky dkk (2017) di Mesir yaitu tentang pengaruh pemberian topikal ASI terhadap pelepasan tali pusat dibandingkan dengan etanol pada bayi baru lahir sehat. Pada penelitian ini, pemberian topikal ASI dan etanol diberikan sejak bayi lahir hingga dua hari setelah tali pusat terlepas. Elsobky (2017) mengatakan bahwa aplikasi topikal ASI pada tali pusat dapat berpengaruh karena adanya faktorfaktor antibakteri, agen imunologi dan antiinfeksi yang terdapat didalam ASI. Kolostrum mengandung sejumlah komponen pelengkap yang bertindak sebagai agen antimikroba alami, dan juga sebagai faktor protektif yang memberikan kekebalan pasif spesifik dan nonspesifik. Dalam penelitian tersebut membuktikan bahwa waktu yang dibutuhkan tali pusat untuk lepas pada kelompok ASI lebih cepat bila dibandingkan dengan kelompok etanol. Oleh karena itu pemberian ASI pada bayi baru lahir sangat dianjurkan.

ASI khususnya kolostrum terbukti mengandung zat-zat bioaktif antara lain immunoglobulin, enzim, sitokin, dan sel-sel yang memiliki fungsi efektif sebagai anti infeksi dan anti inflamasi. Zat-zat bermanfaat yang terdapat dalam kolostrum tersebut, dapat dijadikan bahan alternatif untuk perawatan tali pusat karena cukup steril, murah, mudah didapat, dan mudah dilakukan oleh ibu. Menurut Nirwana (2014) didalam ASI terdapat zat imun yang terletak pada immunoglobulin, sekretori dan laktoferin. Uniknya kandungan nutrisi yang sangat banyak tersebut sangat mudah dicerna dan diserap oleh pencernaan bayi. Hal inilah yang membedakan kandungan ASI dan susu formula, yaitu terletak pada zat imunnya. Sekarang ini, sudah banyak penelitian tentang keefektifitasan pemberian ASI terhadap waktu pelepasan tali pusat, namun penelitian tersebut terbatas pada pemberian secara topikal dan dalam kegiatan praktek masih belum banyak diterapkan. 
Berdasarkan studi pendahuluan yang dilakukan di PMB Ngadillah pada Bulan Maret 2018 didapatkan 8 dari 27 ibu ada yang memberikan ramuan atau obat-obatan tertentu terhadap tali pusat bayi sebelum terlepas. Menurut mereka, pemberian ramuan atau obat-obatan tersebut dapat mempercepat pelepasan tali pusat pada bayinya. Begitu juga saat dilakukan wawancara tentang nutrisi bayinya, sebanyak 12 dari 27 ibu (44,5\%) memberikan ASI saja kepada bayinya, dan sisanya sebanyak 15 dari 27 ibu $(55,5 \%)$ memberikan kombinasi ASI dan susu formula pada bayinya. Hal ini menunjukkan bahwa persentasi pemberian kombinasi ASI dan susu formula pada bayi lebih tinggi dibandingkan dengan pemberian ASI saja.

Berdasarkan uraian diatas maka, peneliti tertarik untuk meneliti perbedaan waktu pelepasan tali pusat bayi antara yang mendapatkan ASI dibandingkan dengan yang mendapat kombinasi ASI dan susu formula. Sehingga dengan adanya penelitian ini dapat memberikan dorongan bagi tenaga kesehatan untuk berupaya meningkatkan dorongan pemberian ASI secara eksklusif tanpa tambahan susu formula atau makanan tambahan apapun pada 6 bulan pertama.

\section{METODE PENELITIAN}

Desain penelitian yang digunakan dalam penelitian ini adalah analitik komparatif dengan menggunakan pendekatan cross sectional. Pada penelitian ini akan ditinjau bagaimana efek pemberian ASI atau kombinasi ASI dan susu formula terhadap waktu pelepasan tali pusat bayi, kemudian akan dibandingkan waktu pelepasan tali pusat bayi antara yang mendapatkan ASI dengan yang mendapatkan kombinasi ASI dan susu formula. Populasi pada penelitian ini adalah seluruh bayi baru lahir di PMB Ngadillah pada tanggal 25 Juni - 1 Agustus 2018 sejumlah 32 bayi baru lahir yang terdiri dari 16 bayi baru lahir yang mendapatkan ASI dan 16 bayi baru lahir yang mendapatkan kombinasi ASI dan susu formula. Sampel pada penelitian ini yaitu bayi baru lahir di PMB Ngadillah pada tanggal 25 Juni -1 Agustus 2018 sejumlah 32 bayi baru lahir yang terdiri dari 16 bayi baru lahir yang mendapatkan ASI dan 16 bayi baru lahir yang mendapatkan kombinasi ASI dan susu formula. Proses pengambilan sampel menggunakan teknik accidental sampling, dimana pengambilan anggota sampel dilakukan dengan cara menunggu ada kelahiran di PMB Ngadillah, kemudian dijadikan sampel. Instrumen yang digunakan adalah pedoman wawancara untuk mengkaji data bayi yang diberikan ASI maupun kombinasi ASI dan susu formula. Sedangkan lembar observasi digunakan untuk mengamati proses lepas dan lamanya waktu pelepasan tali pusat. Variabel-variabel dalam penelitian ini menggunakan skala ukur rasio. Analisa data yang digunakan yaitu uji parametrik Independent T-Test dengan $\alpha=0,05$, dan dinyatakan bermakna apabila $p$ value $<0,05$.

\section{HASIL PENELITIAN}

Berdasarkan hasil penelitian diperoleh data sebagai berikut:

a. Karakteristik Responden Berdasarkan Durasi Menyusui

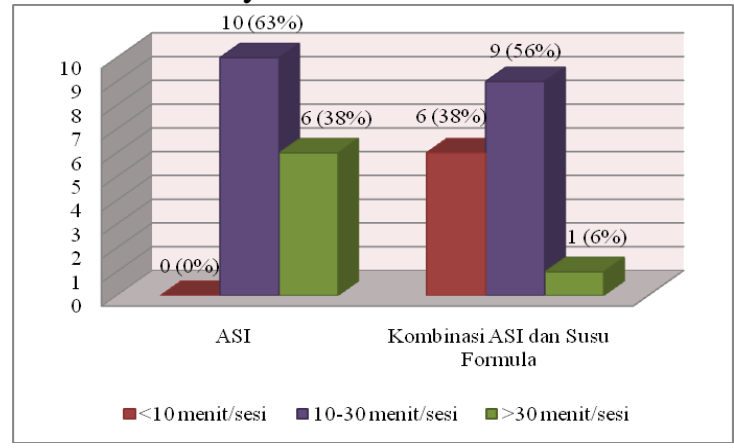

Gambar 1. Diagram Batang Durasi Menyusui

Berdasarkan gambar 1 dapat diketahui bahwa sebagian besar yaitu sebanyak 10 (63\%) responden pada kelompok ASI memiliki durasi menyusui atau menetek selama 10-30 menit/sesi. Begitu pula pada kelompok kombinasi ASI dan susu formula, sebagian besar responden yaitu sebanyak $9 \quad(56 \%)$ responden pada kelompok kombinasi ASI dan susu formula memiliki durasi menyusui pada ibu selama 10-30 menit/sesi.

b. Karakteristik Responden Berdasarkan Frekuensi Menyusui 


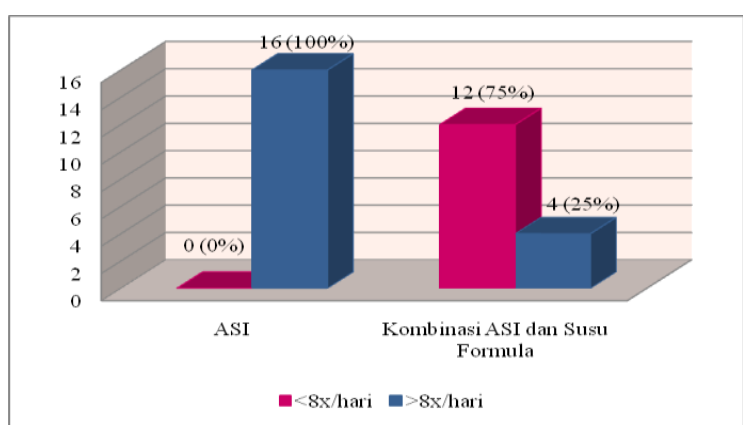

Gambar 2. Diagram Batang Frekuensi

Menyusui

Berdasarkan gambar 2 dapat diketahui bahwa seluruhnya responden pada kelompok ASI menyusu >8x/hari yaitu sebanyak $16(100 \%)$ responden, dan sebagian besar responden pada kelompok kombinasi ASI dan susu formula menyusu $<8 \mathrm{x} /$ hari yaitu sebanyak $12 \quad(75 \%)$ responden.

c. Karakteristik Responden Berdasarkan Frekuensi Pemberian Susu Formula

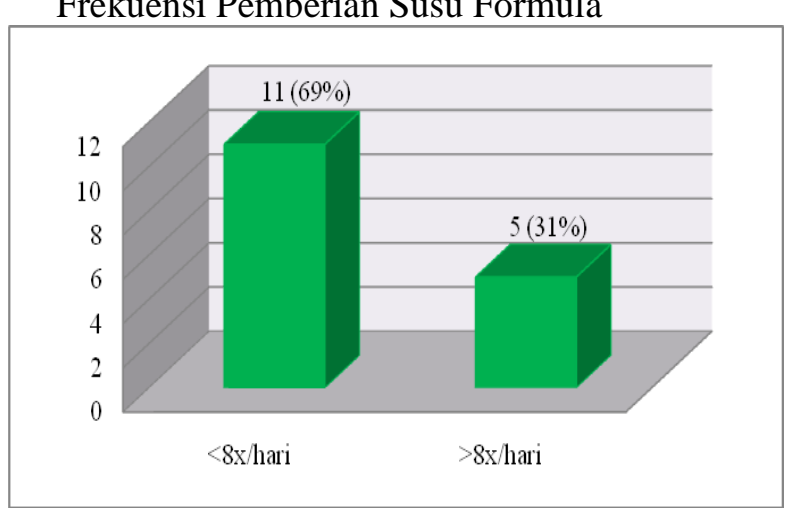

Gambar 3. Diagram Batang Frekuensi

Pemberian Susu Formula

Berdasarkan gambar 3 dapat diketahui bahwa sebagian besar responden pada kelompok kombinasi ASI dan susu formula mengkonsumsi susu formula $<8 x$ /hari yaitu sebanyak $11 \quad(69 \%)$ responden.

d. Waktu Pelepasan Tali Pusat Bayi yang Mendapatkan ASI

Tabel 1. Analisa Waktu Pelepasan Tali Pusat Bayi yang Mendapatkan ASI

\begin{tabular}{cc}
\hline $\begin{array}{c}\text { Analisis } \\
\text { Deskripsi }\end{array}$ & $\begin{array}{c}\text { Waktu Pelepasan Tali Pusat Bayi } \\
\text { yang Mendapatkan ASI (Hari) }\end{array}$ \\
\hline Min & 3 \\
Max & 7 \\
Mo & 5 \\
Md & 5 \\
$-\bar{x}$ & 5
\end{tabular}

SD

Berdasarkan tabel 1 diatas dapat diketahui bahwa dari 16 responden bayi yang mendapatkan ASI didapatkan hasil rata-rata waktu pelepasan tali pusat bayi yang mendapatkan ASI adalah selama 5 hari.

e. Waktu Pelepasan Tali Pusat Bayi yang Mendapatkan Kombinasi ASI dan Susu Formula

Tabel 2. Analisa Waktu Pelepasan Tali Pusat Bayi yang Mendapatkan Kombinasi ASI dan Susu Formula

\begin{tabular}{cc}
$\begin{array}{c}\text { Analisis } \\
\text { Deskripsi }\end{array}$ & $\begin{array}{c}\text { Waktu Pelepasan Tali Pusat } \\
\text { Bayi yang Mendapatkan } \\
\text { Kombinasi ASI dan Sufor (Hari) }\end{array}$ \\
\hline Min & 4 \\
Max & 8 \\
Mo & 7 \\
Md & 7 \\
$\bar{x}$ & 6 \\
SD & 1,26 \\
\hline Berdasarkan tabel 2 diatas dapat
\end{tabular}
diketahui bahwa dari 16 responden bayi yang mendapatkan kombinasi ASI dan susu formula didapatkan hasil rata-rata waktu pelepasan tali pusat bayi yang mendapatkan kombinasi ASI dan susu formula adalah selama 6 hari.

f. Analisa Data

Tabel 3. Analisa Waktu Pelepasan Tali Pusat Bayi yang Mendapatkan ASI dibandingkan dengan Kombinasi ASI dan Susu Formula

\begin{tabular}{|c|c|c|}
\hline & \multicolumn{2}{|c|}{ Waktu Pelepasan Tali Pusat } \\
\hline & ASI & $\begin{array}{c}\text { Kombinasi ASI } \\
\text { dan Susu Formula }\end{array}$ \\
\hline $\mathrm{N}$ & 16 & 16 \\
\hline Mean & 5,1875 & 6,5000 \\
\hline $\mathrm{SD}$ & 1,22304 & 1,26491 \\
\hline $\begin{array}{l}\text { Std. Error } \\
\text { Mean }\end{array}$ & 0,30576 & 0,31623 \\
\hline $\boldsymbol{\alpha}$ & 05 & $\rho=0,006$ \\
\hline
\end{tabular}
penelitian ini dilakukan secara komputerisasi menggunakan uji statistik Independent $T$-test dengan nilai $\alpha=0,05$. Dasar pengambilan keputusan dalam uji Independen T-Test adalah apabila $p$ value $<\alpha(0,05)$ maka $\mathrm{H}_{0}$ ditolak. Hasil uji statistik Independent T-test diperoleh $p$ 
value $=0,006$, karena $p$ value $(0,006)<$ dari $\alpha(0,05)$ maka hipotesis $\mathrm{H}_{0}$ ditolak yang artinya terdapat perbedaan waktu pelepasan tali pusat bayi yang mendapatkan ASI dibandingkan dengan kombinasi ASI dan susu formula di PMB Ngadillah.

\section{PEMBAHASAN}

a. Waktu Pelepasan Tali Pusat Bayi yang Mendapatkan ASI

Berdasarkan penelitian yang telah dilakukan di PMB Ngadillah, selama pengambilan data penelitian berjalan lancar. Saat pertama kali bertemu dengan responden, respon dari keluarga responden sangat baik, bahkan dari keseluruhan responden tidak ada yang menolak untuk ikut serta dalam penelitian ini ataupun mengajukan berhenti mengikuti penelitian selama pengambilan data. Saat dilakukan kunjungan rumah untuk dilakukan observasi dan wawancara, keluarga responden juga memberikan respon yang baik. Ketika dilakukan wawancara seputar pemberian ASI, sebagian besar responden memberikan jawaban dengan jelas dan terbuka terhadap peneliti. Hampir semua ibu yakin dan percaya diri untuk memberikan ASI secara eksklusif terhadap bayinya.

Berdasarkan pada tabel 1, diketahui bahwa dari 16 responden bayi yang mendapatkan ASI di PMB Ngadillah, ratarata waktu pelepasan tali pusat bayi yang mengkonsumsi ASI adalah selama 5 hari dan sebagian besar tali pusat bayi lepas pada hari ke-5.

Pengambilan data pada penelitian ini dilakukan sebanyak 3 kali observasi. Pada observasi hari pertama dilakukan saat bayi lahir, kemudian 2 kali observasi berikutnya dengan melakukan kunjungan rumah. Berdasarkan hasil observasi salah satu responden, kondisi tali pusat pada saat hari pertama yaitu saat bayi baru lahir masih terlihat basah, jeli wharton yang membungkus arteri dan vena terlihat masih sangat tebal, basah dan menempel kuat. Kemudian pada hari ke-3 jeli wharton sudah nampak mulai mengering, menguning dan menyusut. Pada observasi hari ke-5, tali pusat sudah lepas sempurna tanpa menyisakan sisa, dan keadaan daerah sekitar tali pusat tidak menunjukkan tandatanda adanya infeksi.

Waktu pelepasan tali pusat pada bayi dipengaruhi oleh beberapa faktor salah satunya adalah status nutrisi pada bayi. Status nutrisi bayi berkaitan dengan pemberian makanan yang diberikan kepada bayi apakah bayi diberikan ASI saja atau diselingi dengan pemberian susu formula. ASI kaya akan antibody atau zat kekebalan tubuh yang mampu melindungi bayi dari berbagai macam penyakit dan infeksi. Namun kekebalan tubuh pada setiap bayi berbeda, tergantung pada seberapa banyak volume ASI yang diterima oleh bayi, oleh karena itu sistem pertahanan tubuhnya dalam melawan penyakit juga akan berbeda. Volume ASI yang diterima bayi tergantung pada frekuensi dan durasi menyusuinya. Semakin sering dan semakin lama menyusu maka semakin tinggi daya imunitas tubuhnya.

Berdasarkan gambar 1 diperoleh bahwa dari 16 responden kelompok ASI, $10(63 \%)$ responden menyusu selama 1030 menit/sesi, kemudian 6 (38\%) bayi menyusu $>30$ menit/sesi dan tidak ada bayi yang menyusu $<10 \mathrm{menit} / \mathrm{sesi}$. Menurut Dewi (2012) salah satu tanda bayi cukup ASI adalah bayi minum dengan lama menyusui minimal 10 menit setiap sekali menyusu. Pernyataan ini juga sejalan dengan penelitian yang dilakukan oleh Almatsier (2011 dalam Sari dkk 2016) yang menyatakan bahwa durasi menyusui yang baik $>15$ menit pada satu payudara yang berarti jika kedua payudara $>30$ menit, dan pernyataan ini juga didukung oleh WHO (2011 dalam Sari dkk 2016) yang menyatakan durasi menyusui penting untuk pertumbuhan bayi agar bayi mendapatkan gizi yang sempurna pada ASI yang terdapat dalam foremilk (ASI awal) dan hindmilk (ASI akhir). Dengan durasi menyusui yang cukup maka volume kebutuhan ASI yang diterima bayi dapat dicerna dan diserap dengan baik dan bayi akan mendapatkan sistem imun yang kuat.

Berdasarkan gambar 2 diperoleh bahwa keseluruhan dari responden pada kelompok ASI yang berjumlah 16 bayi, 
menyusu atau menetek selama $>8 x /$ hari (100\%). Menurut Dewi (2012) salah satu tanda bayi cukup ASI adalah bayi minum ASI tiap 2-3 jam atau dalam 24 jam minimal mendapatkan ASI 8 kali pada 2-3 minggu pertama. Hal ini juga sejalan dengan penelitian yang dilakukan oleh Sari dkk (2016) bahwa frekuensi menyusui yang lebih sering dalam pemberian ASI akan memberikan gizi yang lebih optimal terhadap bayi. Frekuensi yang lebih sering juga mencegah lambung bayi kosong sehingga setiap saat bisa mencerna gizi untuk pertumbuhannya.

Frekuensi dan durasi menyusi pada penelitian ini berkaitan dengan waktu pelepasan tali pusat pada bayi. Berdasarkan tabel 1 diperoleh bahwa ratarata waktu pelepasan tali pusat bayi yang mendapatkan ASI adalah selama 5 hari dan waktu pelepasan tali pusat paling lama adalah pada hari ke-7. Sehingga, ada beberapa bayi yang mengalami waktu pelepasan tali pusat lebih dari 5 hari bahkan hingga hari ke-7. Hal ini bisa dipengaruhi oleh durasi menyusui dan frekuensi menyusui pada setiap bayi yang berbeda. Pada bayi yang mengalami pelepasan tali pusat lama, durasi menyusui dan frekuensi menyusui bayi lebih sedikit bila dibandingkan dengan bayi yang mengalami pelepasan tali pusat lebih cepat dari 5 hari, sehingga waktu pelepasan tali pusat terjadi sedikit lebih lama dibandingkan dengan bayi yang memiliki durasi menyusui lebih lama dan frekuensi menyusui lebih banyak.

Pada bayi yang mengkonsumsi ASI saja, waktu pelepasan tali pusat cenderung terjadi dengan cepat, hal ini sejalan dengan penelitian yang dilakukan oleh Allam dkk (2015) bahwa kolostrum dalam ASI mengandung sejumlah komponen pelengkap yang bertindak sebagai zat antimikroba alami dan juga dilengkapi dengan faktor-faktor pelindung yang memberikan kekebalan pasif spesifik dan nonspesifik. Begitu kolostrum atau ASI ditelan bayi dan masuk dalam saluran pencernaan, sel makrofag akan melenyapkan bakteri pathogen yang ada atau masuk ke saluran cerna (Tjhin dkk, 2013). Tali pusat yang belum terlepas merupakan tempat masuknya mikroorganisme patogen, oleh karena itu diperlukan sistem kekebalan tubuh yang kuat untuk dapat menangkal bakteri patogen yang masuk dalam tubuh bayi. Allam dkk (2015) juga mengatakan ASI mengandung antibody IgA dalam jumlah yang besar, dan tampaknya ASI ini mempunyai efek pencegahan terhadap infeksi. ASI juga berperan dalam efek antibakteri dan antivirus secara umum. Selain berperan dalam sistem imun yang sempurna. ASI adalah sumber dari dua kelas faktor pertumbuhan, yaitu Transforming Growth Factor alfa dan beta (TGF- $\alpha$ dan TGF- $\beta$ ) dan Insulin Growth Factors 1 dan 2 (IGF-1 dan IGF-2). TGF juga memiliki potensi terapeutik pada rulang dan penyembuhan luka. TGF ini membantu dalam perbaikan jaringan dan mendukung lapisan usus (Thapa, 2005). IGF-1 berperan dalam karakteristik anabolik dan penyembuhan luka. Selain itu protein didalam ASI memiliki keistimewaan yaitu protein dalam ASI mempunyai rasio protein whey: kasein $=$ 60:40, dibandingkan dengan air susu sapi atau susu formula yang rasionya $=20: 80$ (Dewi, 2012). Disini protein whey adalah protein yang mudah diserap dan dicerna oleh bayi, sedangkan protein kasein sulit dicerna dalam pencernaan bayi. Menurut Dewi (2012) kadar poliamin dan nukleotid yang penting untuk sintesis protein pada ASI lebih tinggi dibandingkan air susu sapi atau pada susu formula, sehingga penyerapan protein dalam tubuh bayi yang mengkonsumsi banyak ASI lebih optimal dan peran protein sebagai perbaikan jaringan yang rusak dapat bekerja dengan cepat khususnya pada pelepasan tali pusat.

Seperti yang direkomendasikan oleh Mousa, dkk (2006 dalam Allam dkk, 2015) mengoleskan ASI pada tali pusat merupakan praktek yang bermanfaat mengingat faktor antibakteri yang ada dalam ASI, serta ASI memiliki banyak imunologi dan agen anti-infeksi. Walaupun pada penelitan sebelumnya pemberian ASI pada bayi dilakukan secara eksperimen dengan pemberian secara topikal, namun disini kandungan yang terdapat dalam ASI khususnya kolostrum adalah yang berperan dalam pelepasan tali pusat. Seperti yang telah dijelaskan diatas bahwa tali pusat 
adalah tempat masuknya mikroorganisme asing, dengan adanya kolostrum sebagai zat kekebalan, anti infeksi dan anti bakteri, dapat diserap dengan mudah oleh tubuh bayi, zat-zat tersebut akan menangkal mikroorganisme asing yang masuk melalui luka tali pusat sehingga dapat mengurangi resiko infeksi pada tali pusat dan mempercepat lepasnya tali pusat.

b. Waktu Pelepasan Tali Pusat Bayi yang Mendapatkan Kombinasi ASI dan Susu Formula

Berdasarkan hasil penelitian pada tabel 2, diketahui bahwa dari seluruh responden bayi yang mendapatkan kombinasi ASI dan susu formula di PMB Ngadillah yang berjumlah 16 bayi, ratarata waktu pelepasan tali pusatnya adalah selama 6 hari dan sebagian besar responden, tali pusat lepas pada hari ke-7.

Berdasarkan hasil observasi pada salah satu responden, kondisi tali pusat pada saat hari pertama masih terlihat basah, jeli wharton yang membungkus arteri dan vena terlihat masih sangat tebal dan melekat kuat pada pangkal tali pusat. Kemudian pada hari ke-3 jeli wharton sudah mulai mengering, menguning dan menyusut tetapi masih sedikit tebal. Pada hari ke-7, tali pusat sudah lepas tanpa menyisakan sisa, tetapi keadaan tali pusat yang terlepas belum sepenuhnya mengering.

Seperti yang telah dijelaskan diatas. Salah satu faktor yang mempengaruhi pelepasan tali pusat adalah status nutrisi. Status nutrisi bayi yang mendapatkan ASI maupun yang mendapatkan kombinasi ASI dan susu formula jelas berbeda. Hal ini berkaitan dengan kemampuan sistem pencernaan bayi dalam menyerap zat gizi yang terdapat dalam ASI dan susu formula.

Pada gambar 1 dapat diketahui bahwa durasi menyusui bayi pada kelompok kombinasi ASI dan susu formula paling banyak memiliki durasi menyusui selama 10-30 menit/sesi yaitu sejumlah 9 (56\%) bayi, kemudian sebanyak $6(38 \%)$ bayi memiliki durasi menyusui $<10 \mathrm{menit} / \mathrm{sesi}$, dan hanya ada $1(6 \%)$ bayi yang menyusu >30 menit/sesi. Berdasarkan gambar tersebut, dapat disimpulkan bahwa durasi menyusui setiap bayi memiliki waktu yang berbeda, apalagi pada bayi yang diselingi pemberian susu formula. Maka durasi menyusuinya cenderung membutuhkan waktu yang cepat, karena selain bayi tersebut mendapatkan ASI, bayi juga mendapatkan susu formula.

Begitu pula pada gambar 2 dapat diketahui dari keseluruhan bayi pada kelompok kombinasi ASI dan susu formula yang berjumlah 16 bayi, 12 (75\%) bayi menyusu <8x/hari dan 4 (25\%) bayi menyusu $>8 x /$ hari. Sama halnya dengan durasi menyusui, bahwa pada bayi yang diberikan selingan susu formula, otomatis frekuensi menyusuinya akan lebih sedikit karena selain mendapat ASI, bayi tersebut juga mendapatkan susu formula, sehingga volume ASI yang diterima bayi menjadi sedikit dan zat imun atau zat bermanfaat lain yang terdapat dalam ASI tidak diterima dalam jumlah yang banyak.

Susu formula sebagai salah satu bentuk susu buatan dimana kandungan masing-masing susu formula dapat bervariasi dan berbeda sesuai dengan jenisnya, akan tetapi pada umunya kandungan yang terdapat pada setiap susu formula hampir sama. Walaupun kandungannya hampir mirip dengan ASI, namun pada dasarnya tidaklah sama. Protein pada susu formula mengandung gumpalan yang sulit dicerna oleh sistem pencernaan bayi, padahal manfaat dari protein itu sendiri sebagai pemelihara jaringan dan menggantikan sel-sel yang telah rusak tidak terpakai.

Susu formula merupakan media yang baik bagi pertumbuhan bakteri, oleh karena itu kontaminasi mudah terjadi terutama dalam persiapan dan pemberian susu formula kurang memperhatikan segi kebersihan. Dan masih rendahnya tingkat kesadaran ibu bayi yang kurang memperhatikannya sehingga ketika bayi mengkonsumsi susu formula, susu tersebut sudah terkontaminasi bakteri.

c. Perbedaan Waktu Pelepasan Tali Pusat Bayi yang Mendapatkan ASI dibandingkan dengan Kombinasi ASI dan Susu Formula

Pada penelitian ini, sampel yang dibutuhkan yaitu sebanyak 32 bayi yang terdiri dari 16 bayi baru lahir pada 
kelompok ASI dan 16 bayi baru lahir pada kelompok kombinasi ASI dan susu formula. Rata-rata waktu pelepasan tali pusat bayi yang mendapatkan ASI adalah selama 5 hari dan rata-rata waktu pelepasan tali pusat bayi yang mendapatkan kombinasi ASI dan susu formula adalah 6 hari. Selisih rata-rata waktu pelepasan tali pusat bayi yang mendapatkan ASI saja dan bayi yang mendapatkan kombinasi ASI dan susu formula adalah 1 hari, dimana waktu pelepasan tali pusat bayi pada kelompok ASI terjadi lebih cepat dibandingkan dengan bayi yang mendapatkan kombinasi ASI dan susu formula. Berdasarkan hasil uji hipotesis menggunakan uji Independen T-Test diperoleh hasil $p$ value $=0,006<\alpha$ $=0,05$, sehingga $\mathrm{H}_{0}$ ditolak yang artinya ada perbedaan waktu pelepasan tali pusat bayi yang mendapatkan ASI dibandingkan dengan kombinasi ASI dan susu formula di PMB Ngadillah.

Penelitian ini didukung oleh hasil penelitian yang dilakukan oleh Elsobky (2017) tentang pengaruh pemberian topikal ASI dibandingkan dengan ethanol pada waktu pelepasan tali pusat pada bayi baru lahir sehat menunjukkan bahwa pemberian ASI secara topikal pada pelepasan tali pusat terbukti lebih cepat bila dibandingkan dengan pemberian ethanol. Proses pelepasan tali pusat sangat kompleks, yaitu melalui proses pengeringan dan mumifikasi. Pelepasan tali pusat terjadi karena infiltrasi dari leukosit nuclear polymorph pada puntung tali pusat yang melekat di dinding perut bayi dan terjadi proses pengeringan serta membentuk maserasi. Aplikasi topikal ASI pada tali pusat dapat berpengaruh karena adanya faktor-faktor antibakteri, agen imunologi dan anti-infeksi yang terdapat didalam ASI khususnya kolostrum.

Pada bayi yang mengkonsumsi ASI, faktor-faktor antibakteri, agen imunologi dan anti-infeksi tersebut juga akan masuk ke dalam perut bayi dan akan dicerna oleh sistem pencernaan bayi. ASI sebagai makanan alamiah yang diproduksi oleh ibu untuk bayinya mempunyai zat kekebalan tubuh dan porsi yang ideal bagi tubuh bayi, zat gizi yang terdapat pada ASI ini akan diserap oleh tubuh bayi melalui sistem pencernaan bayi dengan sangat mudah karena memang makanan yang terbaik bagi bayi diawal kehidupannya adalah ASI. Zat anti-infeksi, anti-bakteri dan zat imunologi yang terdapat dalam ASI akan diserap secara maksimal pada bayi yang mendapatkan ASI, sehingga bayi akan mendapatkan perlindungan dengan mengkonsumsi ASI tersebut. Zat tersebut berperan khususnya dalam pengeringan dan pelepasan tali pusat. Tali pusat merupakan tempat masuknya mikroorganisme asing, sehingga semakin cepat tali pusat terlepas akan semakin rendah kemungkinan terjadinya infeksi pada tali pusat bayi.

Perbedaan rata-rata waktu pelepasan tali pusat bayi bisa terjadi karena banyak faktor, seperti pemberian nutrisi. Pemberian nutrisi pada bayi dapat berupa Air Susu Ibu (ASI) atau susu formula. ASI sebagai jenis susu alamiah memiliki komposisi berupa air, lemak, protein, laktosa, vitamin, mineral, dan zat kekebalan tubuh. Namun, konsumsi ASI yang diterima setiap bayi akan berbeda karena setiap bayi memiliki frekuensi dan durasi menyusui yang berbeda pula, apalagi jika bayi diselingi pemberian susu formula, otomatis volume ASI yang didapat juga akan berbeda karena dengan pemberian susu formula, maka bayi tidak akan menerima ASI dalam jumlah banyak, sehingga manfaat zat-zat yang terkandung dalam ASI khususnya zat imun juga berbeda. Selain itu, susu formula dibuat dengan tambahan air untuk melarutkan susu tersebut, penambahan air akan meningkatkan resiko pencampuran bakteri apabila ibu tidak memasak air dan membersihkan tempat susu (botol dot) dengan benar. Berbeda dengan ASI yang langsung dikeluarkan dari puting ibu dan langsung diminumkan kepada bayi, maka kondisi ASI dalam keadaan steril tanpa kontaminasi bakteri.

Berdasarkan uraian diatas dengan banyaknya manfaat dari faktor imun dan faktor pertumbuhan yang terdapat pada ASI terutama kolostrum, akan meminimalkan terjadinya infeksi akibat paparan bakteri patogen yang mungkin dialami oleh bayi baru lahir. Apabila tidak ada paparan bakteri patogen, maka faktor 
pertumbuhan bisa mempercepat penyembuhan dan pelepasan tali pusat bayi.

\section{KESIMPULAN}

a. Rerata waktu pelepasan tali pusat bayi yang mendapatkan ASI adalah selama 5 hari.

b. Rerata waktu pelepasan tali pusat bayi yang mendapatkan kombinasi ASI dan susu formula adalah selama 6 hari.

c. Rerata waktu pelepasan tali pusat bayi yang mendapatkan ASI terjadi lebih cepat dibandingkan dengan bayi yang mendapatkan kombinasi ASI dan susu formula dengan selisih 1 hari.

\section{SARAN}

Bagi praktik mandiri bidan sebaiknya bidan sebagai tenaga kesehatan yang kontak langsung dengan ibu dan anak diharapkan lebih meningkatkan kepedulian para ibu menyusui untuk memberikan ASI eksklusif dengan memberikan informasi cara pemberian ASI yang tepat dan informasi akan pentingnya ASI eksklusif bagi bayi terutama dalam kaitannya dengan waktu pelepasan tali pusat.

Bagi masyarakat diharapkan dapat menerapkan pemberian ASI eksklusif pada 6 bulan pertama, karena ASI memiliki zat antibody, anti-alergi, anti-inflamasi dan zatzat berguna lainnya yang tidak ditemukan pada susu formula. Disamping itu masyarakat disarankan dapat menerapkan perawatan tali pusat yang benar pada bayi baru lahir dengan metode bersih dan kering tanpa membubuhi tali pusat tersebut dengan ramuan atau obat apapun misalnya betadine dan alkohol.

Bagi peneliti selanjutnya diharapkan penelitian ini dapat dikembangkan lagi dengan mengambil jumlah sampel yang lebih banyak, serta pengumpulan data yang lebih mendetail terutama data durasi menyusui harus lebih dikaji lagi dan dilakukan observasi secara langsung untuk memastikan seberapa banyak volume ASI yang diterima oleh setiap responden.

\section{DAFTAR PUSTAKA}

Abata, Qorry 'Aina. 2015. Merawat Bayi Baru Lahir. Yogyakarta: Pustaka Pelajar.
Allam, Nehal A., Wafa A. AL Megrin, Amal M. Talat. 2015. The Effect of Topical Application of Mother Milk on Separation of Umbilical Cord for Newborn Babies. American Journal of Nursing Science. Vol. 4, No. 5, hlm.288-296. Diambil dari: http://article.sciencepublishinggroup.co m/pdf/10.11648.j.ajns.20150405.16.pdf . (12 Desember 2017)

Dewi, Vivian Nanny Lia dan Tri Sunarsih. 2012. Asuhan Kebidanan pada Ibu Nifas. Jakarta: Salemba Medika.

Elsobky, Fatma Ahmed dkk. 2017. Effect of Topical Application on Mother Milk on Umbilical Cord Stump Separation Time Compared To Ethanol in Healthy Newborn. Vol. 4,Issue 1, pp: (1-11). Diambil dari: http://www.noveltyjournals.com/downl oad.php?file=Effect $\% 20$ of $\% 20$ Topical $\% 20$ Application\%20of\%20Mother889.pdf\&act=book. (2 Desember 2017)

Kementerian Kesehatan RI. 2017. Profil Kesehatan Indonesia Tahun 2016. Jakarta: Kementerian Kesehatan RI.

Kementerian Kesehatan RI. 2017. Profil Kesehatan Provinsi Jawa Timur Tahun 2016. Surabaya: Kementerian Kesehatan RI.

Nirwana, Ade Benih. 2014. ASI dan Susu Formula: Kandungan dan Manfaat ASI \& Susu Formula. Yogyakarta: Nuha Medika.

Sari, Dewi Kartika, dkk. 2016. Hubungan Teknik, Frekuensi, Durasi, dan Asupan Energi Ibu Menyusui Eksklusif dengan Berat Badan Bayi Usia 1-6 Bulan di Kecamatan Tasikmadu Kabupaten Karanganyar. Karangayar: Pascasarjana Ilmu Gizi Universitas Sebelas Maret. Diambil dari: https://digilib.uns.ac.id/dokumen/downl oad/239973/MjM5OTcz.

Subiastutik, Eni. 2012. Efektifitas Pemberian Topikal ASI dibanding Perawatan Kering terhadap Kecepatan Waktu 
Lepas Tali Pusat. Jurnal IKESMA, Vol. 8, No. 1, hlm 17-26. Diambil dari: https://jurnal.unej.ac.id/index.php/IKES MA/article/view/1106/892.

November 2017)

Thapa, B. R. 2005. Health Factors in Colostrum. Indian J Pediatri. 72 (7). 579-578. Diambill dari: http://medind.nic.in/icb/t05/i7/icbt05i7p 579.pdf . (2 Desember 2017)

Tjhin, Linda, dkk. 2013. Milk \& Colostrum Book (Keajaiban dan Manfaat Susu \& Kolostrum). Jakarta: Elex Media Komputindo. 